\title{
Silvopastoral system with Eucalyptus as a strategy for mitigating the effects of climate change on Brazilian pasturelands
}

\author{
CRISTIAM BOSI, JOSÉ RICARDO M. PEZZOPANE \& PAULO CESAR SENTELHAS
}

\begin{abstract}
The aim of the present study was to assess the effect of Eucalyptus trees in a silvopastoral system on the microclimate and the capacity of that to mitigate the effects of climate change on pasturelands. This study included an open pasture of Piatã palisadegrass and an adjacent pasture that contained both palisadegrass and Eastto-West rows of Eucalyptus trees, with $15 \mathrm{~m}$ between rows, $2 \mathrm{~m}$ between trees within rows. The micrometeorological measurements were collected at several distances from the tree rows and in the open pasture. The silvopastoral system was associated with greater between-row shading when solar declination was high and greater near-tree shading when solar declination was around $-22^{\circ}$. Both soil heat flux and temperature were influenced by solar radiation, wind speed, and the ability of tree canopies to reduce radiation losses. Wind speed was consistently lower in the silvopastoral system, owing to the windbreak effect of the Eucalyptus trees. The present study demonstrated that silvopastoral systems can be used to attenuate the effects of climate change, as trees can protect pastureland from intense solar radiation and wind, thereby reducing evapotranspiration and, consequently, improving soil water availability for the understory crop.
\end{abstract}

Key words: Agroforestry, microclimate, net radiation, shading, soil heat flux, windbreak.

\section{INTRODUCTION}

Agroforestry systems (AFSs) are characterized by the combined use of land for timber or fruit trees and crops and/or livestock, either simultaneously or sequentially (Lundgren and Raintree 1982), and silvopastoral systems, specifically, are characterized by the combined use of land for trees or shrubs and for pastureland and livestock (Nair 1993). In general, the main goal of AFSs is to optimize land use (Alao \& Shuaibu 2013) by combining forest and food production systems (King 1979), improving soil conservation (Pattanayak \& Mercer 1998), reducing the need to acquire new land area for agriculture (Schroeder 1994), and reducing the need for external inputs (Filius 1982). However, the establishment of AFSs can cause microclimatic changes (Monteith et al. 1991) that can affect systems negatively if such systems are improperly planned.

The microclimates of AFSs depend on a variety of factors, including system design, arrangement, orientation, age, species composition, and architecture, all of which interact at macro- and meso-scales, and the main changes achieved through conversion to AFSs are caused by shade, which is provided by trees and reduces the solar radiation reaching sub-canopy crops (Pezzopane et al. 2015). Indeed, by reducing solar radiation, shade affects a variety of microclimatic variables, 
including air and soil temperatures, relative humidity, soil moisture (Pezzopane et al. 2015), and evapotranspiration (Lin 2010), which affect crop growth (Bosi et al. 2014), and by reducing wind speed, tree plantings can also indirectly affect a variety of other microclimate variables (Pezzopane et al. 2015). According to Gomes et al. (2016), AFS can promote the microclimate stability of understory species by reducing soil water evaporation and run-off and by reducing air and soil temperatures, as reported by Amadi et al. (2016), who studied shelterbelts in Saskatchewan, Canada. Therefore, the ability of AFS establishment to modify microclimates and to improve the resilience of agricultural systems should be considered when comparing different strategies for adapting agriculture to climate change (Montagnini et al. 2013, Nguyen et al. 2013).

In this context, the aim of the present study was to assess the effect of Eucalyptus trees in a silvopastoral system on the microclimate and the capacity of that to mitigate the effects of climate change on pasturelands.

\section{MATERIALS AND METHODS}

\section{Study site}

The study was conducted from August 2013 to June 2016 in São Carlos, São Paulo, Southern Brazil ( $22^{\circ} 01^{\prime} \mathrm{S}, 47^{\circ} 53^{\prime} \mathrm{W}$, alt $860 \mathrm{~m}$ ), where the climate is characterized as Cwa (Köppen), with a cool and dry season from April to September (mean air temperature of $19.9^{\circ} \mathrm{C}$; and total rainfall of $250 \mathrm{~mm}$ ), and a warm and wet season from October to March (mean air temperature of $23.0^{\circ} \mathrm{C}$; and total rainfall of $1100 \mathrm{~mm}$ ), according to Alvares et al. (2014). The study included a 6-ha open pasture of the palisadegrass Urochloa (syn. Brachiaria) brizantha (Hochst ex A. Rich.) Stapf 'BRS Piatã', which was a full-sun system, and a second 6-ha pasture, which contained the same palisadegrass with rows of Eucalyptus urograndis (E. grandis × E. urophylla) 'GG100', which served as the silvopastoral system. The trees in the silvopastoral system were planted in April 2011 and were arranged in simple rows, with an East-to-West orientation, with $15 \mathrm{~m}$ between rows, $2 \mathrm{~m}$ between trees within rows, and density of 333 trees ha ${ }^{-1}$.

\section{Weather and tree measurements}

To assess the effects of the Eucalyptus trees on the microclimatic conditions of the pastureland, sample sites were established at four different distances (SP1, $0.00 \mathrm{~m}$; SP2, $3.75 \mathrm{~m}$; SP3, 7.50 m; SP4, $11.25 \mathrm{~m}$ ) from the Northernmost row of trees, which was responsible for causing shading during most of the year. A full-sun pasture (FS) was also established and considered as the control (Figure 1).

Three weather stations were installed in the study area: one in the open pasture, at 200 $\mathrm{m}$ from the silvopastoral system, and two into the silvopastoral system. Each weather station included linear quantum sensors (Apogee, Logan, UT, USA), a net radiometer (NR-Lite2; Kipp \& Zonen, Delft, Netherlands), a heat flux plate (HFP01; Hukseflux, Delft, Netherlands), an ultrasonic anemometer (Windsonic; Gill Instruments, Lymington, UK), a thermohygrometer (HC2-S3; Rotronic, Bassersdorf, Switzerland), and a soil temperature probe (Thermistor 107; Campbell Scientific, Logan, UT, USA), which measured photosynthetically active radiation (PAR), net radiation ( $\mathrm{Rn})$, soil heat flux (SHF), wind speed, air temperature and relative humidity, and soil temperature, respectively.

Measurements were taken continuously (Figure 1), and the sensors were connected to a data logger (CR3000; Campbell Scientific, Logan, UT, USA) that was configured to record measurements every $5 \mathrm{~s}$ and to calculate 15- and 60-min averages and/or totals. Daily averages, 


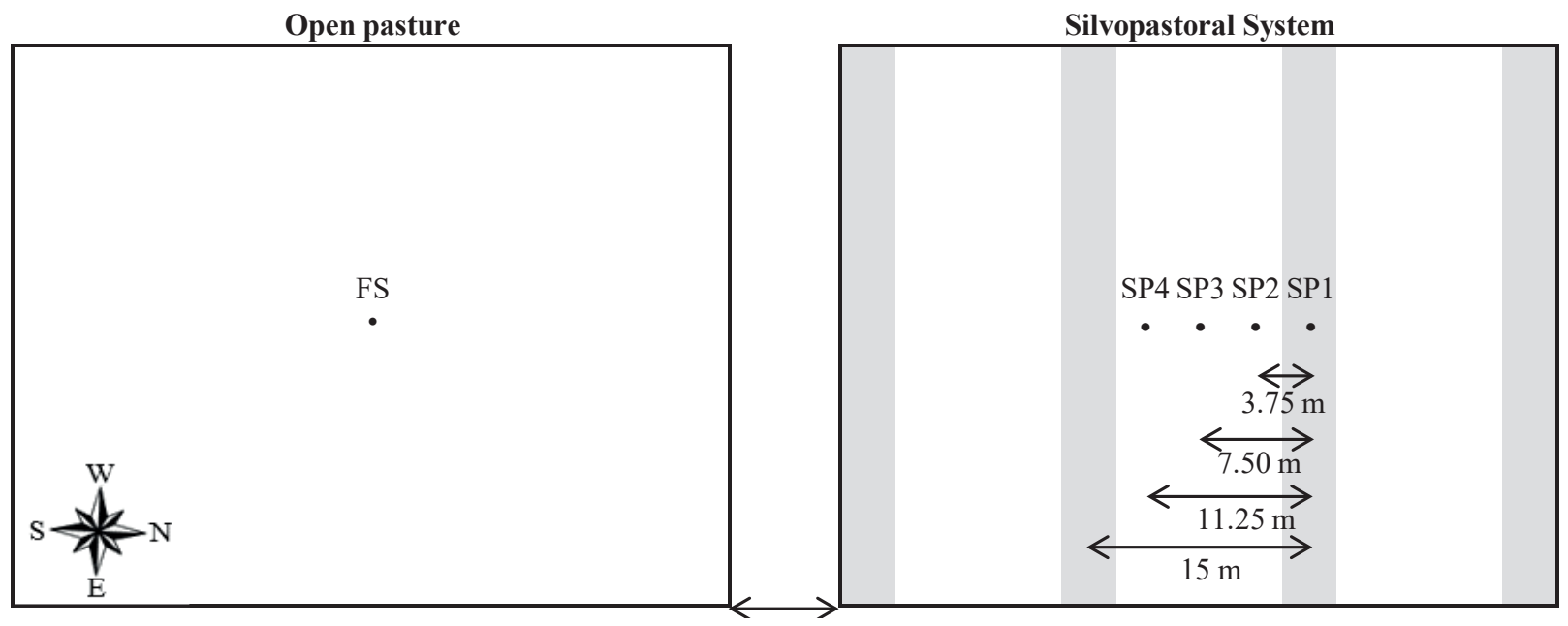

Figure 1. Schematic representation of the study area indicating where the data were collected in the open pasture (left) and in the silvopastoral system (right). FS: full sun, SP1: 0.00 m, SP2: 3.75 m, SP3: 7.50 m, SP4: 11.25 m from North row. Gray strips illustrate the tree rows.

maximums, and minimums were also calculated for air temperature, relative air humidity, and soil temperature, whereas only average and maximum values were calculated for wind speed. For PAR, Rn, and SHF, only daily total values were recorded. The sensors were installed at $1.7 \mathrm{~m}$ height, except for linear quantum sensors, which were installed at $0.6 \mathrm{~m}$ above the soil surface, and the heat flux plates and soil temperature probes, which were deployed $0.05 \mathrm{~m}$ depth in the soil. PAR was measured throughout the study period (August 2013 to June 2016), whereas wind speed, air temperature, relative humidity, and soil temperature were only measured from June 2014 to June 2016, and both Rn and SHF were only measured from December 2014 to June 2016 (Figure 2), and PAR was measured at all the sample sites, whereas the other variables were only measured at the FS, SP1, and SP3 sites. Finally, PAR transmission (PARt) was calculated by dividing the PAR measured at each position of the silvopastoral system by that measured at the open pasture.
The potential of the silvopastoral system to mitigate the effects of climate change was defined as the ability of the Eucalyptus trees to reduce PAR, Rn, wind speed, and air temperature and to increase relative humidity and was assessed by comparing the microclimatic conditions of the SP1 and SP3 sites with those of the FS site for each season of the year.

During the study period, the trees in the four rows close to the weather stations were also evaluated at least every 6 months (04/17/2013, 10/15/2013, 04/08/2014, 10/03/2014, 12/12/2014, 02/03/2015, 05/26/2015, 10/01/2015, 01/27/2016, and 06/02/2016), and each evaluation included the measurement of: each tree's height and crown base height, using a clinometer; canopy width, using a metric tape; and diameter at breast height (DBH, 1.3 $\mathrm{m}$ above the ground), using a diametric tape (Table I).

\section{Statistical analysis}

The study was performed using a completely randomized design with repeated measures, and the data were analyzed using the MIXED 


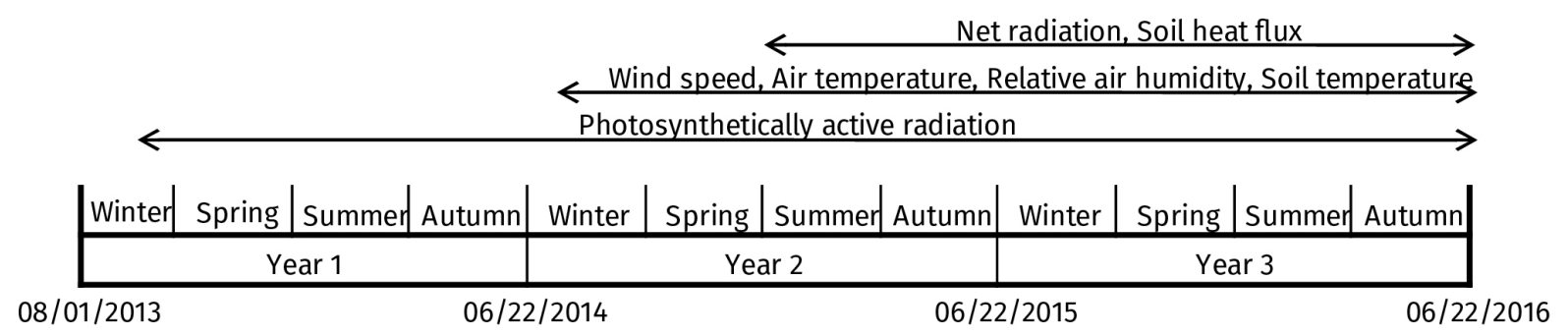

Figure 2. Weather measurements during the three years of the study.

Table I. Tree height, crown base height (CBH), canopy width, and diameter at breast height (DBH) of trees, in a silvopastoral system, measured in several dates of each study year.

\begin{tabular}{|c|c|c|c|c|c|}
\hline \multirow{2}{*}{ Date } & \multirow{2}{*}{ Season/Year } & Tree height & CBH & Canopy width & DBH \\
\cline { 3 - 6 } & & $\mathbf{m}$ & $\mathbf{m}$ & $\mathbf{m}$ & $\mathbf{c m}$ \\
\hline $4 / 17 / 2013$ & - & 10.8 & - & 4.3 & 10.2 \\
\hline $10 / 15 / 2013$ & Spring/1 & 13.0 & - & 5.2 & 12.8 \\
\hline $4 / 8 / 2014$ & Autumn/1 & 16.5 & - & 5.5 & 15.0 \\
\hline $10 / 3 / 2014$ & Spring/2 & 17.7 & - & 5.0 & 16.1 \\
\hline $12 / 12 / 2014$ & Spring/2 & 18.5 & 5.1 & 5.6 & 17.3 \\
\hline $2 / 3 / 2015$ & Summer/2 & 20.0 & 5.3 & 5.5 & 17.7 \\
\hline $5 / 26 / 2015$ & Autumn/2 & 20.1 & 5.5 & 6.5 & 19.1 \\
\hline $10 / 1 / 2015$ & Spring/3 & 22.4 & 6.6 & 6.1 & 20.1 \\
\hline $1 / 27 / 2016$ & Summer/3 & 23.7 & 6.7 & 7.0 & 20.8 \\
\hline $6 / 2 / 2016$ & Autumn/3 & 26.4 & 9.3 & 6.1 & 21.7 \\
\hline
\end{tabular}

procedure of SAS (Littell et al. 2006). To analyze average and maximum wind speed and average, maximum, and minimum air temperature, relative humidity and soil temperature, the repeated factors were year (2 and 3; Figure 2) and season, being the comparison between seasons only within each study year, and each day of a season was considered a replicate, with 92 days or replicates per season. Rn and SHF were analyzed using the same procedure, except that seasons were used as the repeated factors and that only the last six seasons (summer and autumn of year 2 and all seasons of year 3 ), and PAR and PARt were analyzed by a similar process but using data from all three years and considering each $10-d$ period as a replicate (nine replicates per season), in order to reduce the dataset's variation and to improve the normality of its distribution. Means were compared using the Tukey test $(P \geq 0.05)$.

\section{RESULTS}

\section{Solar radiation dynamics}

During the winter and autumn, PAR at the FS site was greater than at all the SP positions (SP1-4), except during the winter of year 1, when the PAR of the FS and SP4 sites were similar (Table II), whereas differences between the PAR of the SP positions were generally not significant $(P<0.05)$. During the spring, PAR incidence was usually greater at the FS position than at the SP positions, except during the spring of year 1, when only the SP1 position received less PAR 
Table II. Photosynthetically active radiation (PAR) incidence at the full sun (FS) and at the four positions within the silvopastoral system (SP1: 0.00 m, SP2: 3.75 m, SP3: $7.50 \mathrm{~m}$ and SP4: $11.25 \mathrm{~m}$ from the North row), in each season of the three study years.

\begin{tabular}{|c|c|c|c|c|c|c|}
\hline \multirow{3}{*}{ Year } & \multirow{3}{*}{ Position } & \multicolumn{5}{|c|}{ PAR } \\
\hline & & \multicolumn{5}{|c|}{ MJ $m^{-2}$ day $^{-1}$} \\
\hline & & Winter & Spring & Summer & Autumn & Average \\
\hline \multirow{6}{*}{1} & FS & $8.08 \mathrm{Aab}^{\star}$ & $8.84 \mathrm{Aab}$ & $10.25 \mathrm{Aa}$ & $6.76 \mathrm{Ab}$ & 8.53 \\
\hline & SP1 & $3.86 \mathrm{BCa}$ & $1.60 \mathrm{Ba}$ & $1.97 \mathrm{Ba}$ & $2.90 \mathrm{Ba}$ & 2.43 \\
\hline & SP2 & $1.54 \mathrm{Cb}$ & $7.01 \mathrm{Aa}$ & $7.18 \mathrm{Aa}$ & 1.90 Bb & 4.74 \\
\hline & SP3 & 5.16 BCab & $7.39 \mathrm{Aa}$ & $8.38 \mathrm{Aa}$ & 2.16 Bb & 5.86 \\
\hline & SP4 & $7.22 \mathrm{ABa}$ & $6.59 \mathrm{Aa}$ & $7.50 \mathrm{Aa}$ & $3.17 \mathrm{Bb}$ & 6.02 \\
\hline & Average & 5.17 & 6.28 & 7.06 & 3.38 & \\
\hline \multirow{6}{*}{2} & FS & $7.03 \mathrm{Aa}$ & $8.76 \mathrm{Aa}$ & $8.77 \mathrm{Aa}$ & $6.10 \mathrm{Aa}$ & 7.66 \\
\hline & SP1 & $3.55 \mathrm{Ba}$ & $3.03 \mathrm{Ca}$ & $2.46 \mathrm{Ba}$ & $1.99 \mathrm{Ba}$ & 2.78 \\
\hline & SP2 & $2.07 \mathrm{Bbc}$ & $5.07 \mathrm{BCab}$ & $5.32 \mathrm{ABa}$ & $1.67 \mathrm{BC}$ & 3.58 \\
\hline & SP3 & $1.72 \mathrm{Bb}$ & $6.04 \mathrm{Ba}$ & $6.33 \mathrm{Aa}$ & $1.67 \mathrm{Bb}$ & 3.93 \\
\hline & SP4 & $3.06 \mathrm{Bbc}$ & $5.81 \mathrm{Ba}$ & 5.30 ABab & $2.10 \mathrm{BC}$ & 4.06 \\
\hline & Average & 3.49 & 5.74 & 5.64 & 2.70 & \\
\hline \multirow{6}{*}{3} & FS & $6.24 \mathrm{Aa}$ & $8.18 \mathrm{Aa}$ & $8.51 \mathrm{Aa}$ & $6.50 \mathrm{Aa}$ & 7.36 \\
\hline & SP1 & $2.16 \mathrm{Ba}$ & $2.86 \mathrm{Ba}$ & $2.27 \mathrm{Ba}$ & $1.93 \mathrm{Ba}$ & 2.31 \\
\hline & SP2 & $2.11 \mathrm{Ba}$ & $4.15 \mathrm{Ba}$ & $4.06 \mathrm{Ba}$ & $1.81 \mathrm{Ba}$ & 3.05 \\
\hline & SP3 & $1.86 \mathrm{Bb}$ & $5.12 \mathrm{Ba}$ & $4.70 \mathrm{Bab}$ & 1.75 Bb & 3.40 \\
\hline & SP4 & $1.93 \mathrm{Bb}$ & $4.61 \mathrm{Ba}$ & 3.97 Bab & $1.75 \mathrm{Bb}$ & 3.10 \\
\hline & Average & 2.86 & 4.98 & 4.70 & 2.75 & \\
\hline
\end{tabular}

*Means followed by the same upper case letter are not different in column, and those followed by the same lower case letter are not different in line $(P<0.05)$.

(difference of $7.24 \mathrm{MJ} \mathrm{m}^{-2} \mathrm{~d}^{-1}$ ). During the summer of year 3, PAR at the FS site was greater than that at all the SP positions, and during years 1 and 2, PAR at the FS position was only greater than that at the SP1. On average, PAR reduction at the SP1 and SP3 positions was 5.29 and $3.48 \mathrm{MJ} \mathrm{m}^{-2}$ $\mathrm{d}^{-1}$, respectively (Table III). PAR values of the SP1 position were always similar between seasons and comprised between 1.60 and $3.86 \mathrm{MJ} \mathrm{m}^{-2}$ $\mathrm{d}^{-1}$. At the other SP positions, PAR was generally greater during the spring and summer. The PARt during the winter and autumn were similar among all four SP positions, except for during the winter of year 1 , when that of the SP4 position (86.6\%) was significantly greater than that of the SP2 (22.1\%; Figure 3 and Table IV). During the spring and summer, PARt was lower at the SP1 position than at the other positions, with few exceptions. The hourly dynamics of PAR varied by year. During the first year, PAR incidence was greater at the FS, SP3, and SP4 positions than at the SP1 and SP2 positions, which indicated that the trees caused more shading at SP1 and SP2 (Figure 4). During subsequent years, PAR decreased at the SP3 and SP4 positions, which demonstrated shadow at these positions.

Net radiation was greater at the FS position than at the SP positions, except during the summer of year 2, when the Rn of the FS and SP3 positions (11.32 and $10.13 \mathrm{MJ} \mathrm{m}^{-2} \mathrm{~d}^{-1}$, respectively) were similar (Table V). The Rn of the SP1 position was either similar or greater than that of the SP3 position, and the mean $\mathrm{Rn}$ reductions observed at the SP1 and SP3 positions were 5.17 and $3.08 \mathrm{MJ}$ $\mathrm{m}^{-2} \mathrm{~d}^{-1}$, respectively, with the greatest reductions observed during the spring and summer at the SP1 position and during the winter and autumn at the SP3 position (Table III). 
(a)

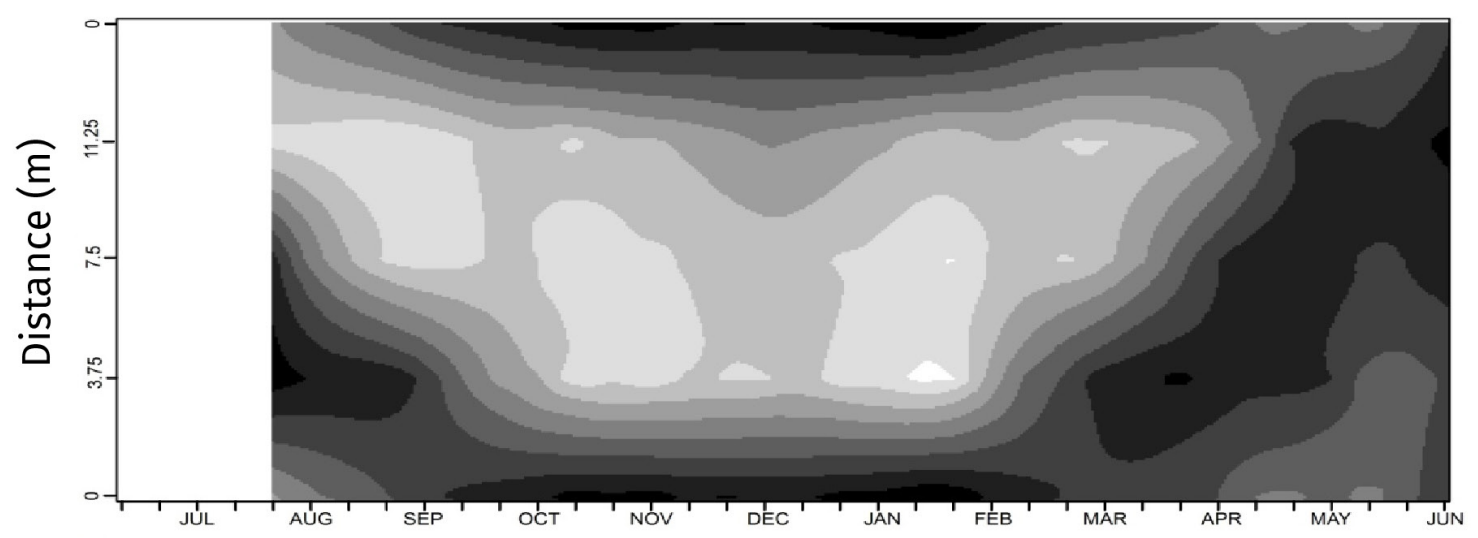

(b)

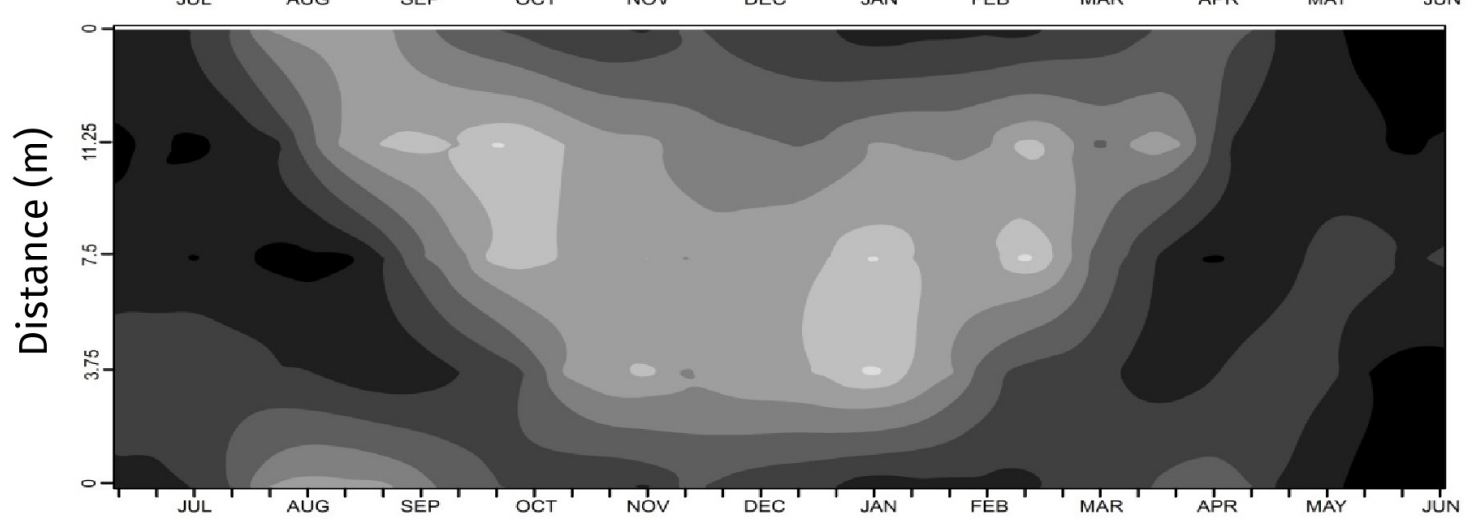

(c)

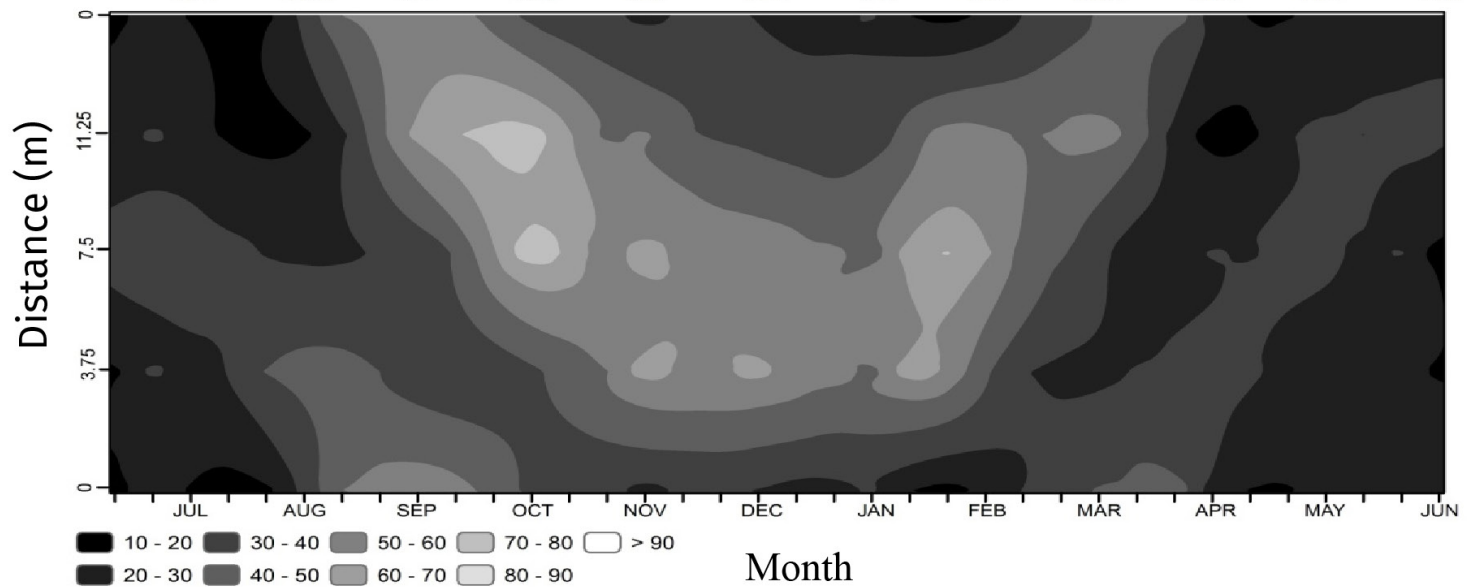

Figure 3. Spatial and temporal photosynthetically active radiation transmission (PARt) between rows of a silvopastoral system, every ten-day period during the three years of the study, from July to June. (a) year 1 (starting from August 2013), (b) year 2, and (c) year 3. Interpolation made by the Natural Neighbor method. 
Table III. Mean reductions of photosynthetically active radiation (PAR), net radiation (Rn), average wind speed (WSavg), maximum wind speed (WSmax), average air temperature (Tavg) and average relative air humidity (RHavg), every season, at $0.00 \mathrm{~m}$ (SP1) and $7.50 \mathrm{~m}$ (SP3) from the North row, in a silvopastoral system.

\begin{tabular}{|c|c|c|c|c|c|c|}
\hline \multirow{2}{*}{ Variable } & \multirow{2}{*}{ Position } & \multicolumn{4}{|c|}{ Season } & \multirow[b]{2}{*}{ Average } \\
\hline & & Winter & Spring & Summer & Autumn & \\
\hline \multirow{2}{*}{$\begin{array}{c}\text { PAR } \\
\left(\text { MJ } \mathrm{m}^{-2} \mathrm{day}^{-1}\right)\end{array}$} & SP1 & 3.93 & 6.09 & 6.95 & 4.18 & 5.29 \\
\hline & SP3 & 4.21 & 2.41 & 2.71 & 4.59 & 3.48 \\
\hline \multirow{2}{*}{$\begin{array}{c}\mathrm{Rn} \\
\left(\mathrm{MJ} \mathrm{m}^{-2} \mathrm{day}^{-1}\right)\end{array}$} & SP1 & 2.87 & 6.67 & 7.90 & 3.25 & 5.17 \\
\hline & SP3 & 4.04 & 1.92 & 1.95 & 4.4 & 3.08 \\
\hline \multirow{2}{*}{$\begin{array}{l}\text { WSavg } \\
\left(\mathrm{m} \mathrm{s}^{-1}\right)\end{array}$} & SP1 & 0.91 & 1.01 & 0.80 & 0.64 & 0.84 \\
\hline & SP3 & 0.93 & 1.00 & 0.81 & 0.66 & 0.85 \\
\hline \multirow{2}{*}{$\begin{array}{l}\text { WSmax } \\
\left(\mathrm{m} \mathrm{s}^{-1}\right)\end{array}$} & SP1 & 3.30 & 3.59 & 3.50 & 2.84 & 3.30 \\
\hline & SP3 & 3.28 & 3.48 & 3.35 & 2.98 & 3.26 \\
\hline \multirow{2}{*}{$\begin{array}{l}\text { Tavg } \\
\left({ }^{\circ} \mathrm{C}\right)\end{array}$} & SP1 & 0.03 & -0.09 & 0.17 & 0.13 & 0.03 \\
\hline & SP3 & 0.10 & -0.22 & -0.04 & 0.29 & 0.02 \\
\hline \multirow{2}{*}{$\begin{array}{c}\text { RHavg } \\
(\%)\end{array}$} & SP1 & -0.46 & -0.12 & -2.23 & 0.41 & -0.50 \\
\hline & SP3 & -0.84 & 0.00 & -1.79 & 0.74 & -0.36 \\
\hline
\end{tabular}

Table IV. Photosynthetically active radiation (PAR) transmission at the four positions within the silvopastoral system (SP1: $0.00 \mathrm{~m}, \mathrm{SP2}: 3.75 \mathrm{~m}, \mathrm{SP3}: 7.50 \mathrm{~m}$ and SP4: $11.25 \mathrm{~m}$ from the North row), in each season of the three study years.

\begin{tabular}{|c|c|c|c|c|c|c|}
\hline \multirow{3}{*}{ Year } & \multirow{3}{*}{ Position } & \multicolumn{5}{|c|}{ PAR transmission } \\
\hline & & \multicolumn{5}{|c|}{$\%$} \\
\hline & & Winter & Spring & Summer & Autumn & Average \\
\hline \multirow{5}{*}{1} & SP1 & 47.1 ABa* & $20.5 \mathrm{Bb}$ & $20.3 \mathrm{Bb}$ & 43.8 Aa & 31.3 \\
\hline & SP2 & $22.1 \mathrm{Bb}$ & 75.8 Aa & $68.3 \mathrm{Aa}$ & $30.6 \mathrm{Ab}$ & 52.4 \\
\hline & SP3 & 62.2 ABab & 80.3 Aa & $80.4 \mathrm{Aa}$ & $32.3 \mathrm{Ab}$ & 64.2 \\
\hline & SP4 & $86.6 \mathrm{Aa}$ & $71.8 \mathrm{Aa}$ & $72.1 \mathrm{Aa}$ & $44.4 \mathrm{Ab}$ & 66.9 \\
\hline & Average & 54.5 & 62.1 & 60.3 & 37.8 & \\
\hline \multirow{5}{*}{2} & SP1 & 48.1 Aa & $35.9 \mathrm{Ba}$ & $29.4 \mathrm{Ba}$ & $30.2 \mathrm{Aa}$ & 36.0 \\
\hline & SP2 & 31.3 Aab & $56.4 \mathrm{Aa}$ & $56.6 \mathrm{Aa}$ & $27.1 \mathrm{Ab}$ & 43.3 \\
\hline & SP3 & $25.0 \mathrm{Ab}$ & $66.5 \mathrm{Aa}$ & $67.7 \mathrm{Aa}$ & $28.8 \mathrm{Ab}$ & 47.0 \\
\hline & $\mathrm{SP} 4$ & 41.0 Aab & $64.1 \mathrm{Aa}$ & $58.3 \mathrm{Aa}$ & $32.8 \mathrm{Ab}$ & 49.0 \\
\hline & Average & 36.3 & 55.7 & 53.0 & 29.7 & \\
\hline \multirow{5}{*}{3} & SP1 & $32.7 \mathrm{Aa}$ & 35.3 Ba & 27.7 Ba & $28.8 \mathrm{Aa}$ & 31.2 \\
\hline & SP2 & $34.0 \mathrm{Aab}$ & 49.6 Aa & 45.1 ABab & $27.4 \mathrm{Ab}$ & 39.2 \\
\hline & SP3 & $31.5 \mathrm{Ab}$ & $60.1 \mathrm{Aa}$ & 52.2 Aab & $27.5 \mathrm{Ab}$ & 43.3 \\
\hline & SP4 & $30.1 \mathrm{Aab}$ & 54.6 Aa & 45.3 ABab & $27.8 \mathrm{Ab}$ & 39.8 \\
\hline & Average & 32.1 & 49.9 & 42.6 & 27.9 & \\
\hline
\end{tabular}

*Means followed by the same upper case letter are not different in column, and those followed by the same lower case letter are not different in line $(P<0.05)$. 
Table V. Net radiation and soil heat flux, at full sun (FS) and at two positions within a silvopastoral system (SP1: $0.00 \mathrm{~m}$ and SP3: $7.50 \mathrm{~m}$ from the North row), in six seasons.

\begin{tabular}{|c|c|c|c|c|c|c|c|}
\hline \multirow{2}{*}{ Position } & \multicolumn{7}{|c|}{ Season/Year } \\
\hline & Summer/2 & Autumn/2 & Winter/3 & Spring/3 & Summer/3 & Autumn/3 & Average \\
\hline & \multicolumn{7}{|c|}{ Net Radiation } \\
\hline & \multicolumn{7}{|c|}{ MJ m ${ }^{-2}$ day $^{-1}$} \\
\hline FS & $11.32 \mathrm{Aa}^{*}$ & $6.25 \mathrm{Ab}$ & $5.43 \mathrm{Ab}$ & $10.43 \mathrm{Aa}$ & $10.60 \mathrm{Aa}$ & $6.03 \mathrm{Ab}$ & 8.34 \\
\hline SP1 & $2.85 \mathrm{Ba}$ & $3.00 \mathrm{Ba}$ & $2.56 \mathrm{Ba}$ & $3.76 \mathrm{Ca}$ & $3.27 \mathrm{Ca}$ & $2.79 \mathrm{Ba}$ & 3.04 \\
\hline SP3 & $10.13 \mathrm{Aa}$ & $1.74 \mathrm{BC}$ & $1.39 \mathrm{BC}$ & $8.51 \mathrm{Bab}$ & $7.90 \mathrm{Bb}$ & $1.74 \mathrm{BC}$ & 5.27 \\
\hline \multirow[t]{3}{*}{ Average } & 8.10 & 3.66 & 3.13 & 7.57 & 7.26 & 3.52 & \\
\hline & \multicolumn{7}{|c|}{ Soil Heat Flux } \\
\hline & \multicolumn{7}{|c|}{ MJ m ${ }^{-2} \mathrm{day}^{-1}$} \\
\hline FS & $-0.01 \mathrm{Aa}$ & $-0.11 \mathrm{Aab}$ & $0.13 \mathrm{Aa}$ & $0.02 \mathrm{ABa}$ & $-0.24 \mathrm{Abc}$ & $-0.42 A C$ & -0.11 \\
\hline SP1 & $-0.13 \mathrm{ABa}$ & $-0.37 \mathrm{BC}$ & $-0.15 \mathrm{Bab}$ & $-0.07 \mathrm{Ba}$ & $-0.12 \mathrm{Aa}$ & $-0.34 \mathrm{Abc}$ & -0.19 \\
\hline SP3 & $-0.28 \mathrm{BC}$ & $-0.27 A B C$ & $-0.08 \mathrm{Bb}$ & $0.20 \mathrm{Aa}$ & $-0.07 A b$ & $-0.35 \mathrm{AC}$ & -0.14 \\
\hline Average & -0.14 & -0.25 & -0.03 & 0.05 & -0.14 & -0.37 & \\
\hline
\end{tabular}

*Means followed by the same upper case letter are not different in column, and those followed by the same lower case letter are not different in line $(P<0.05)$.

The SHF of the FS position was generally similar to that of the SP1 and SP3 positions but was sometimes greater than that of either one or the other (Table V). Analysis of the hourly values of $\mathrm{Rn}$ and SHF revealed that the greatest nighttime radiation and heat losses occurred at the FS position (Figure 5), as did the greatest day-time Rn and SHF occurred at the FS position, followed by the SP3 and SP1 positions, respectively.

\section{General microclimatic conditions}

Average wind speed was greater at the FS position than at the SP positions, with a difference of 1.2 $\mathrm{m} \mathrm{s}^{-1}$ between the SP1 and FS positions (Table VI), and the SP positions consistently yielded similar average wind speed values. A similar pattern was observed for maximum wind speed, with reductions of up to $3.85 \mathrm{~m} \mathrm{~s}^{-1}$ at the SP positions. The hourly wind speed dynamics indicated that the wind speed of the FS position was greater than that of the SP positions throughout the day, with the greatest differences observed during the morning (Figure 6a, b). On average, there was a substantial reduction of wind speed at the SP positions during all seasons, especially for maximum wind speed, the average reduction of which was $3.28 \mathrm{~m} \mathrm{~s}^{-1}$ (Table III).

The average wind speed of the FS position was generally greatest during the spring, whereas that of the SP positions was more consistent. Meanwhile, maximum wind speed was greater during the spring, regardless of position, and decreased gradually from winter to autumn (Table VI).

Average, maximum, and minimum air temperature and relative humidity were statistically similar among the FS, SP1, and SP3 positions, regardless of season, with the exception of the minimum relative humidity of the summer of year 3 , when it was more humid at the SP1 position than at the FS position (64.8 and 54.9\%, respectively; Table VI). The hourly variation in air temperature and relative humidity were also similar among the positions. 

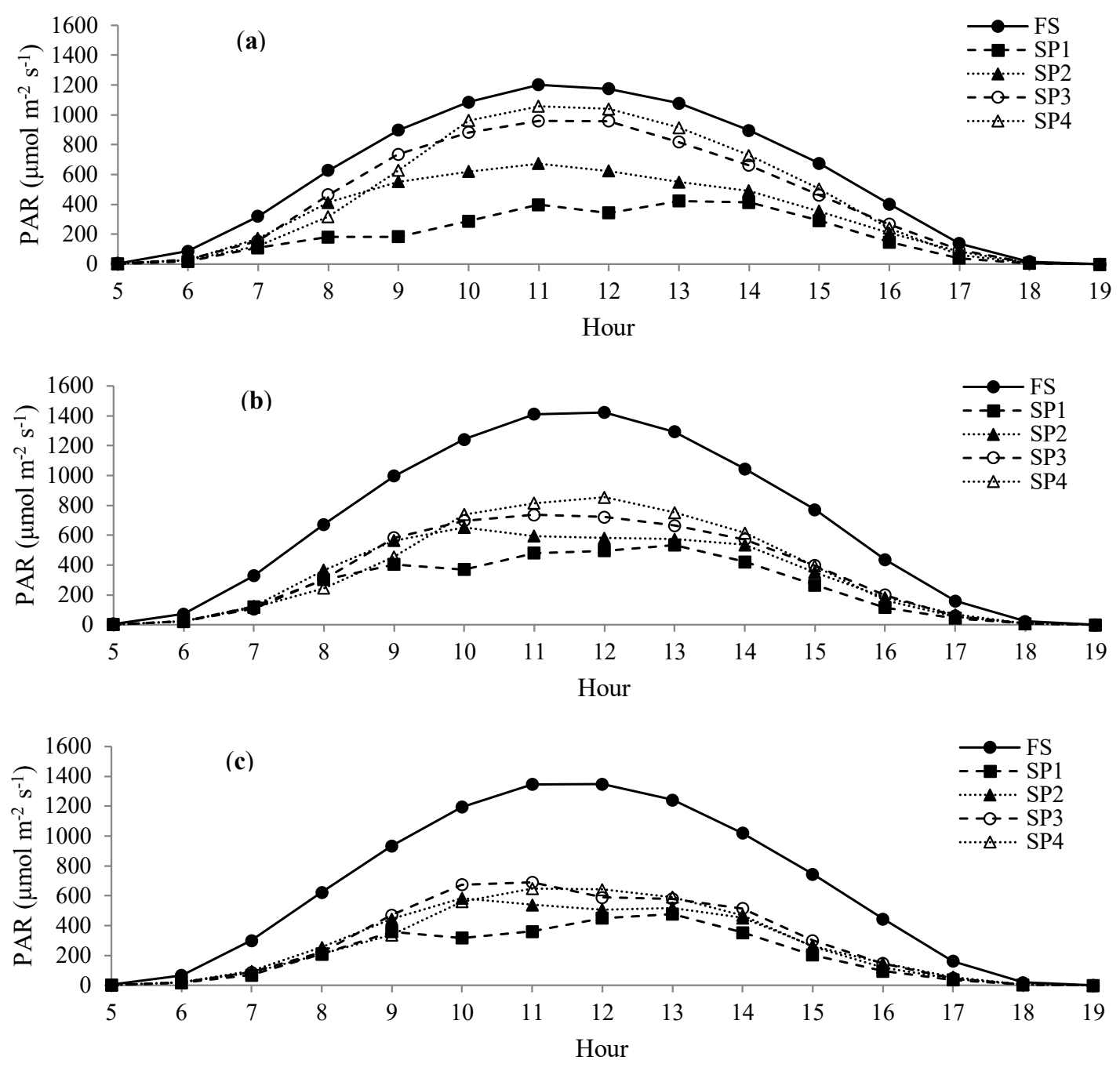

Figure 4. Average photosynthetically active radiation at full sun (FS) and at the four positions within a silvopastoral system (SP1: 0.00 m, SP2: $3.75 \mathrm{~m}$, SP3: $7.50 \mathrm{~m}$ and SP4: $11.25 \mathrm{~m}$ from the North row), in three study years. a: year 1, b: year 2, c: year 3 .

The average, maximum, and minimum soil temperatures were generally greater than those of the SP1 and SP3 positions but were sometimes similar to either one or both of the SP positions and rarely even lower than those of either one or the other SP positions. In general, variation in average hourly soil temperature was greater during the day than during the night, with consistently greater values at the FS position (Figure 6c, d).

\section{DISCUSSION}

\section{Factors influencing microclimate}

The Eucalyptus rows promoted a shadow range projection in the silvopastoral area that was parallel to the tree rows. The East-to-West orientation of the trees resulted in little shadow movement throughout the day, and thus, the shadows were projected at the same distance from the tree rows during a great part of the day. On the other hand, the orientation promoted 

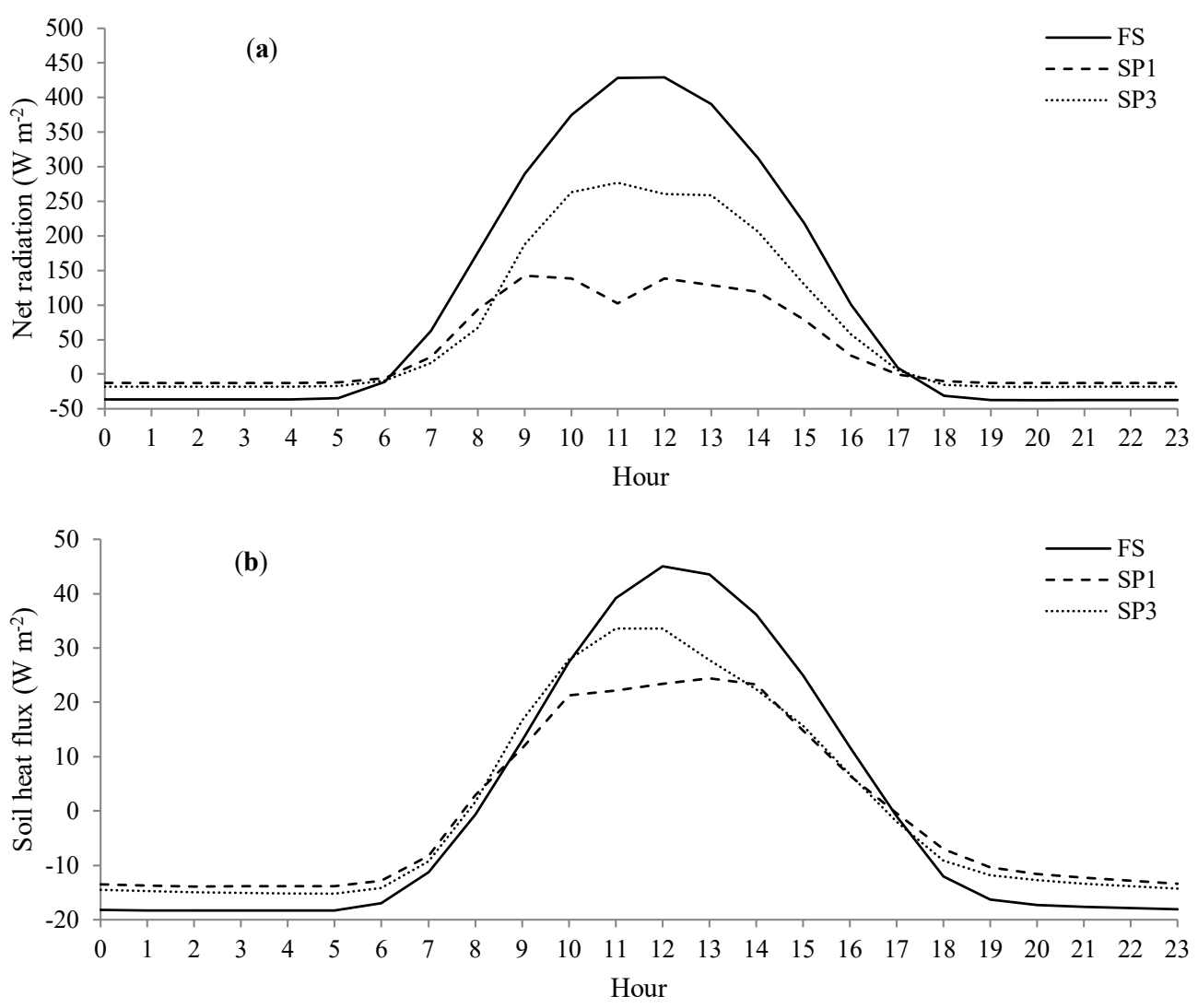

Figure 5. Average net radiation (a) and soil heat flux (b) at full sun (FS) and at two different positions within a silvopastoral system (SP1: $0.00 \mathrm{~m}$ and SP3: $7.50 \mathrm{~m}$ from the North row).

intense shadow variation throughout the year, due to changes in solar declination, with the North-to-South shadow length varying greatly, according to the period of the year (Figure 3, Tables II and III).

During the winter and autumn, neither the PAR or PARt of the SP positions varied significantly because the solar declination during these seasons was high, thereby projecting shadows at all the SP positions. However, this pattern was not observed when tree height was low ( 12 $\mathrm{m}$; Table I) or when the solar declination was insufficient to project significant shadows at SP4 (Table II and Table IV). In fact, during the spring and summer of year 1, significant shadows were only observed at the SP1 position, owing to insufficient tree height, but as the trees grew, the shadow height increased significantly, especially during the third year, when tree height reached $\sim 25 \mathrm{~m}$ (Table I). This PAR dynamics, caused by tree growth, can be observed in the hourly PAR values of each study year (Figure 4).

Prasad et al. (2010) reported a PARt of $40 \%$ at $0.5 \mathrm{~m}$ from rows of 4-year-old Eucalyptus trees (11-m spacing), and Oliveira et al. (2007) reported that PAR was greater between rows of 4.5-year-old Eucalyptus trees (15-m spacing) than below the tree canopies (difference of 762 $\mu \mathrm{mol} \mathrm{m} \mathrm{m}^{-2} \mathrm{~s}^{-1}$ ). In addition, Siles et al. (2010), who evaluated microclimate in a coffee-based AFS in Costa Rica that was shaded by Inga densiflora Benth., reported a PARt of $\sim 40 \%$ during the dry season and of $25 \%$ during the wet season. 

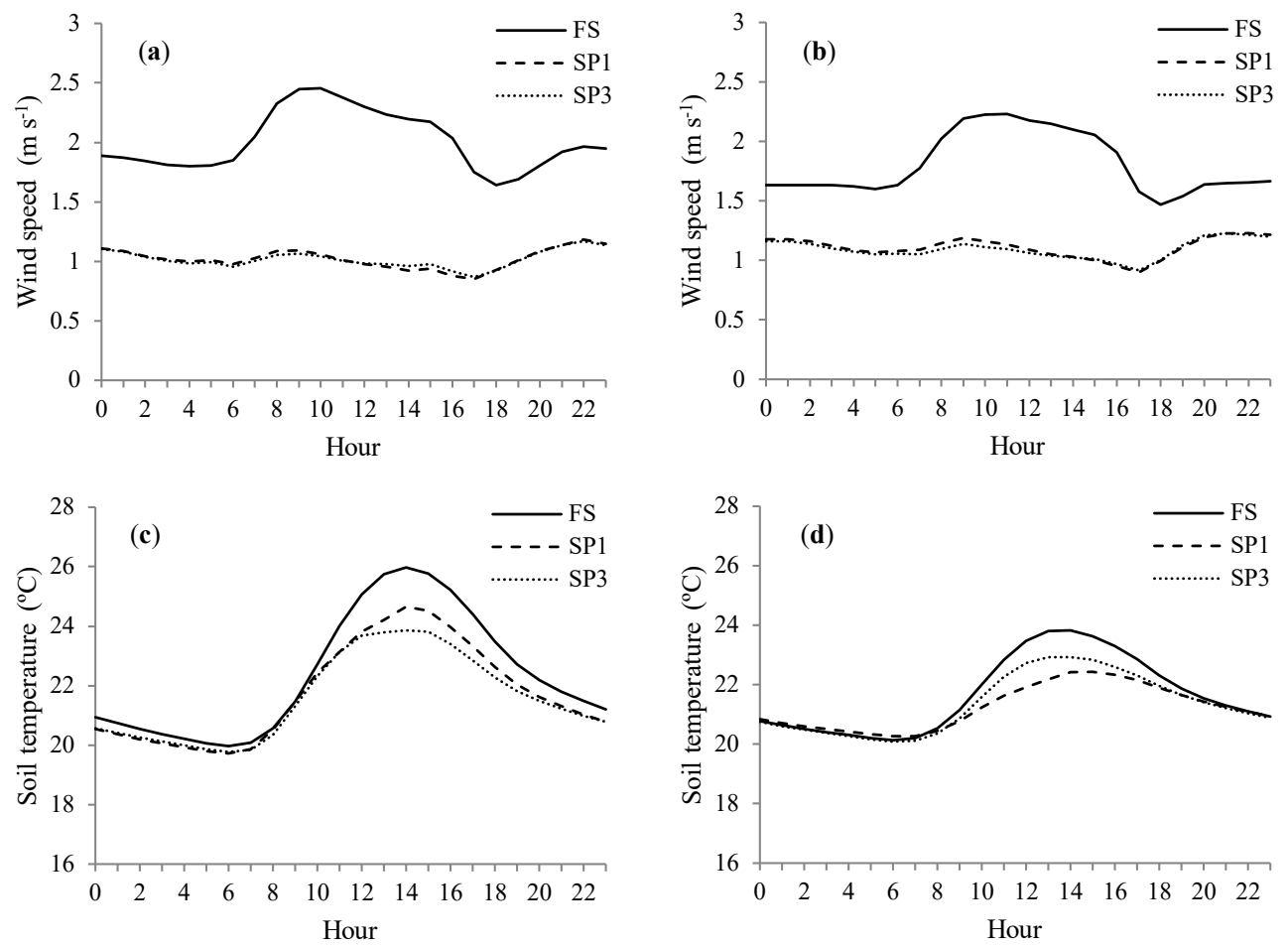

Figure 6. Average wind speed $(a, b)$ and soil temperature $(c, d)$ in the study years $2(a, c)$ and 3 (b, d) at different positions: full sun (FS), below row (SP1), and $7.50 \mathrm{~m}$ from the North row (SP3).

In the present study, Rn was strongly influenced by solar radiation incidence and, thus, by tree height and solar declination. During the winter and autumn, Rn was greater at the FS position, owing to the relatively high solar declination and low solar radiation incidence of the silvopastoral system. During the spring and summer, the differences were attributed to the strong shading of the SP1 position and weak shading of the SP3 position.

Soil heat flux was affected by solar radiation incidence, wind speed, and the effects of tree canopies on radiation losses, including the reflection and re-emission of long-wave radiation to the soil. The importance of each factor varied, depending on position and season, although solar radiation incidence was the most determinant factor.
Wind speed was consistently lower in the silvopastoral system, owing to the arrangement of the trees in rows, the short spacing between trees in each row $(2 \mathrm{~m})$, the high crown base height (Table I), and, likely, the prevailing wind direction, which was transverse to the tree rows. The wind speed reduction mainly occurred during the day, especially during the morning, when solar radiation-mediated changes in air temperature caused air movement. Tamang et al. (2010) reported that the average wind speed reduction at the leeside of 8-m-tall cadaghi (Corymbia torelliana syn. Eucalyptus torelliana (F. Muell.) KD Hill \& LAS Johnson) windbreaks was up to $50 \%$, especially when the wind direction was perpendicular to the windbreak. Böhm et al. (2014) also reported that the wind speed of alley cropping systems, with black locust, was reduced to $80 \%$ of open areas. 


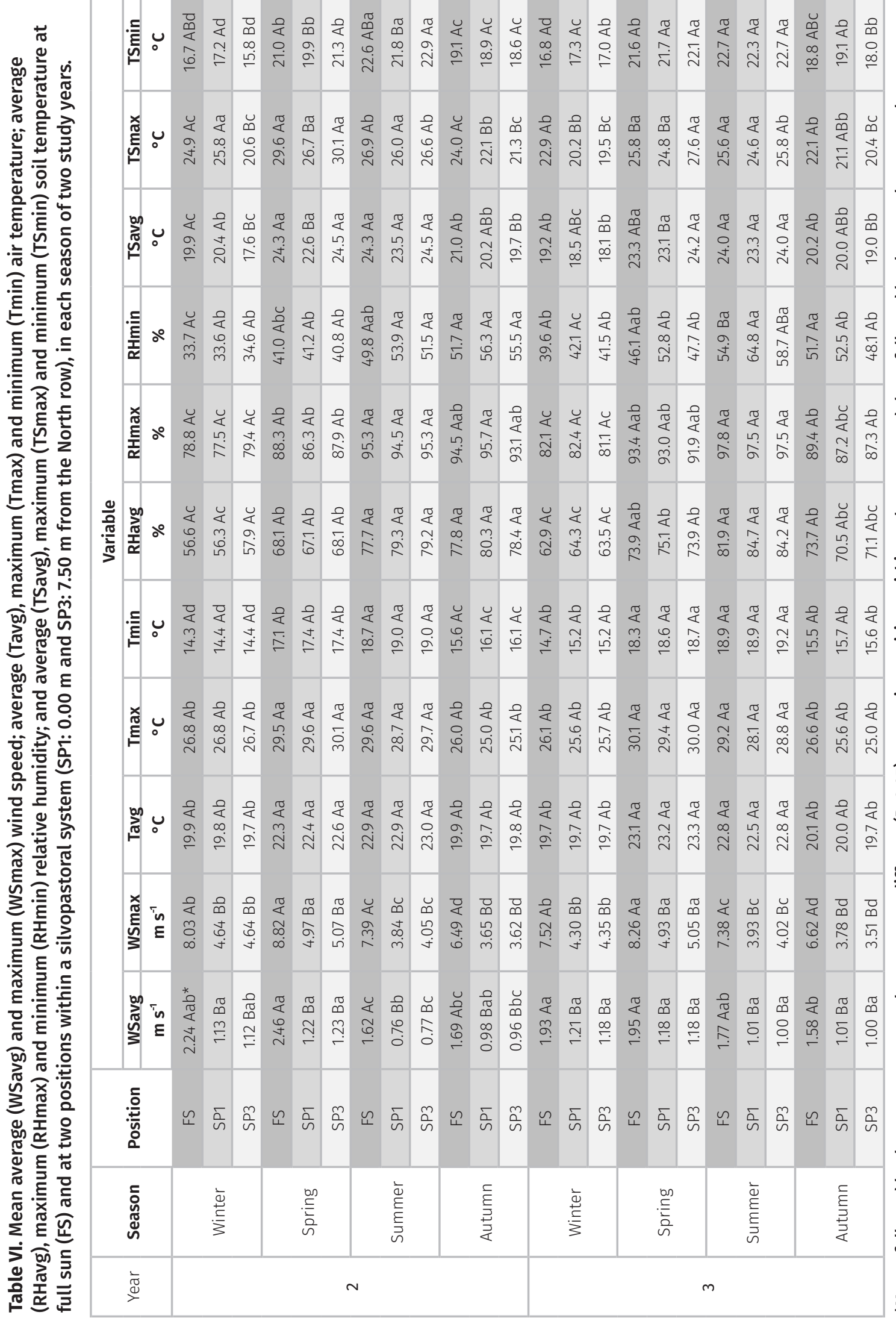


Air temperature and relative humidity were not different among the assessed positions, since the system design and tree species allowed high canopy porosity and, consequently, enough air movement to suppress such differences. In contrast, Karki \& Goodman (2015) reported that the air temperature of a silvopastoral system with mature loblolly pine was $2.3^{\circ} \mathrm{C}$ lower than that of open pasture, and Pezzopane et al. (2015), who evaluated a silvopastoral system with North-to-South rows of native trees in Brazil, reported that the air temperature was higher and the relative humidity was lower near the tree rows than those either between rows or in the full sun. Therefore, microclimatic changes in silvopastoral systems are affected by their design and the specific structure of the tree species used.

In the present study, soil temperature was affected by solar radiation incidence, wind speed, and the effects of tree canopies on longwave radiation balance. These results contradict those of Karky \& Goodman (2015). Indeed, these authors reported that the soil temperature of a silvopastoral system was consistently lower than that of open pasture, regardless of season, whereas the present study found that such differences were only observed in certain seasons (Table VI). However, Amadi et al. (2016) reported that soil temperature was greater in cropped fields in Saskatchewan, Canada, than in shelterbelts, but only during certain seasons. For example, during late summer and early autumn, when the crop fields cooled more quickly, the soil temperature of the crop fields was actually lower than that of the shelterbelts.

In this context, it is possible to conclude that a silvopastoral system with East-to-West oriented rows causes shadow movement throughout the year, which promotes greater shading between rows when solar declination is high and greater shading near trees when solar declination is close to the local latitude $\left(22^{\circ} \mathrm{S}\right)$. Net radiation is strongly influenced by incoming solar radiation and also depends on the factors that affect the shading. Soil heat flux and temperature are also affected by incoming solar radiation, but wind speed and the effects of canopies on radiation losses may be more important. In the present study, wind speed was consistently lower in the silvopastoral system, especially during the day, owing to the arrangement of trees in rows and the short spacing between plants within rows, which formed an effective windbreak. Air temperature and relative humidity did not differ between the open area and silvopastoral system, likely owing to the high canopy porosity, which allowed enough air movement between the areas.

\section{Use of silvopastoral systems for mitigating climate change effects}

According to the IPCC (2013), temperature increase and rainfall reduction will be significant in many regions of the world. Thus, protection from solar radiation, such as that provided by the silvopastoral system, may be very important for mitigating climate change effects in locations where evapotranspiration increases as a function of higher temperature, lower rainfall, and lower cloudiness. The silvopastoral system design assessed in the present study significantly reduced solar radiation incidence, mainly at positions that were closer to the tree rows, and these changes were more evident during the spring and summer, when solar radiation incidence was greater and when high solar radiation, especially close to noon, can affect plants and animals negatively.

Excessively high leaf temperatures can cause plant stress and, consequently, reduce photosynthesis (Boyer 1971), as well as plant growth and productivity. Siles etal.(2010) reported that the leaf temperature of coffee plants grown in full-sun was greater than the air temperature, 
whereas that of shaded coffee was consistently lower. In animals, body temperature determines thermal comfort (Baliscei et al. 2012), as well as productivity and reproductive efficiency (Garcia et al. 2010). Baliscei et al. (2013) measured black globe temperature, which is strongly correlated with animal body temperature, and reported lower values in a silvopastoral system than in an open area. The Rn and wind speed reductions in the silvopastoral systems could contribute to the reduction of pasture evapotranspiration.

Meanwhile, the wind speed reductions observed in the present study confirm the great capacity of silvopastoral systems to reduce excessive wind speeds or strong gusts, which are likely to increase with climate change (IPCC 2013) and which have been associated with both physical damages to plants (Tamang et al. 2010) and stress in animals (Mader et al. 1997). However, in the present study, the Eucalyptus planting failed to significantly affect either air temperature or relative humidity. Therefore, other system designs should be investigated, in order to protect plants and animals from changes in these variables.

Analyzing the potential of silvopastoral systems to attenuate the effects of climate change has revealed that protection from solar radiation can be very important for locations where rainfall and cloudiness are reduced, and reductions in net radiation and wind speed, as observed in the present study, may be important for reducing the evapotranspiration of understory plants of silvopastoral systems, for ensuring more soil water availability for them, and for protecting plants from excessive winds and strong gusts.

\section{Acknowledgments}

We are grateful to the Fundação de Amparo à Pesquisa do Estado de São Paulo (FAPESP) for a scholarship (grant 2014/11931-8) granted to the first author, Conselho Nacional de Desenvolvimento Científico e Tecnológico
(CNPq) for financial support (grant 478067/2013-5), and to Empresa Brasileira de Pesquisa Agropecuária (EMBRAPA Agrossilvipastoril) for cession of the weather stations.

\section{REFERENCES}

ALAO JS \& SHUAIBU RB. 2013. Agroforestry practices and concepts in sustainable land use systems in Nigeria. J Hortic For 5: 156-159.

ALVARES CA, STAPE JL, SENTELHAS PC, GONCALVES JLM \& SPAROVEK G. 2014. Köppen's climate classification map for Brazil. Meteorol Z 22: 711-728.

AMADI CC, VAN REES KCJ \& FARRELL RE. 2016. Soil-atmosphere exchange of carbon dioxide, methane and nitrous oxide in shelterbelts compared with adjacent cropped fields. Agric Ecosyst Environ 223: 123-134.

BALISCEI MA, BARBOSA OR, SOUZA W, COSTA MAT, KRUTZMANN A \& QUEIROZ EO. 2013. Microclimate without shade and silvopastoral system during summer and winter. Acta Sci Anim Sci 35: 49-56.

BALISCEI MA, SOUZA W, BARBOSA OR, CECATO U, KRUTZMANN A \& QUEIROZ EO. 2012. Behavior of beef cattle and the microclimate with and without shade. Acta Sci Anim Sci 34: 409-415.

BÖHM C, KANZLER M \& FREESE D. 2014. Wind speed reductions as influenced by woody hedgerows grown for biomass in short rotation alley cropping systems in Germany. Agrofor Syst 88: 579-591.

BOSI C, PEZZOPANE JRM, SENTELHAS PC, SANTOS PM \& NICODEMO MLF. 2014. Productivity and biometric characteristics of signal grass in a silvopastural system. Pesqui Agropecu Bras 49: 449-456.

BOYER JS. 1971. Nonstomatal inhibition of photosynthesis in sunflower at low leaf water potentials and high light intensities. Plant Physiol 48: 532-536.

FILIUS AM. 1982. Economic aspects of agroforestry. Agrofor Syst 1: 29-39.

GARCIA AR, MATOS LB, LOURENCO JUNIOR JB, NAHUM BS \& COSTA NA. 2010. Increased reproductive efficiency of dairy buffaloes due to silvopastoral system adoption in the Eastern Amazon. Rev Vet 21: 914-915.

GOMES LC, CARDOSO IM, MENDONCA ES, FERNANDES RBA, LOPES VS \& OLIVEIRA TS. 2016. Trees modify the dynamics of soil $\mathrm{CO} 2$ efflux in coffee agroforestry systems. Agric For Meteorol 224: 30-39.

IPCC. 2013. Climate Change 2013: The Physical Science Basis. Contribution of Working Group I to the Fifth 
Assessment Report of the Intergovernmental Panel on Climate Change, 1st ed., Cambridge: Cambridge University Press.

KARKI U \& GOODMAN MS. 2015. Microclimatic differences between mature loblolly-pine silvopasture and openpasture. Agrofor Syst 89: 319-325.

KING KFS. 1979. Agroforestry and the utilisation of fragile ecosystems. Agrofor Syst 2: 161-168.

LIN BB. 2010. The role of agroforestry in reducing water loss through soil evaporation and crop transpiration in coffee agroecosystems. Agric For Meteorol 150: 510-518.

LITTELL RC, MILLIKEN GA, STROUP WW, WOLFINGER RD \& SCHABENBERGER O. 2006. SAS for mixed models, 2nd ed., Cary: SAS Institute, 828 p.

LUNDGREN BO \& RAINTREE JB. 1982. Sustained agroforestry. In: Nestel B (Ed), Agricultural Research for Development: Potentials and Challenges in Asia, 1st ed., The Hague: ISNAR, p. 37-49.

MADER TL, DAHLQUIST JM \& GAUGHAN JB. 1997. Wind protection effects and airflow patterns in outside feedlots. J Anim Sci 75: 26-36.

MONTAGNINI F, IBRAHIM M \& RESTREPO EM. 2013. Silvopastoral systems and climate change mitigation in Latin America. Bois et forêts des tropiques 2: 3-15.

MONTEITH JL, ONG CK \& CORLETT JE. 1991. Microclimatic interactions in agroforestry systems. For Ecol Manag 45: 31-44.

NAIR PKR. 1993. An introduction to Agroforestry, 1st ed., Dordrecht: Kluwer Academic Publishers, 499 p.

NGUYEN Q, HOANG MH, ÖBORN I \& NOORDWIJK MV. 2013. Multipurpose agroforestry as a climate change resiliency option for farmers: an example of local adaptation in Vietnam. Clim Change 117: 241-257.

OLIVEIRA TK, MACEDO RLG, VENTURIN N, BOTELHO SA, HIGASHIKAWA EM \& MAGALHAES WM. 2007. Solar radiation in understory of agrosilvopastoral system with eucalypt on different spacings. Cerne 13: 40-50.

PATTANAYAK S \& MERCER DE. 1998. Valuing soil conservation benefits of agroforestry: contour hedgerows in the Eastern Visayas, Philippines. Agric Econ 18: 31-46.

PEZZOPANE JRM, BOSI C, NICODEMO MLF, SANTOS PM, CRUZ PG \& PARMEJIANI RS. 2015. Microclimate and soil moisture in a silvopastoral system in southeastern Brazil. Bragantia 74: 110-119.

PRASAD JVNS ET AL. 2010. Tree row spacing affected agronomic and economic performance of
Eucalyptus-based agroforestry in Andhra Pradesh, Southern India. Agrofor Syst 78: 253-267.

SCHROEDER P. 1994. Carbon storage benefits of agroforestry systems. Agrofor Syst 27: 89-97.

SILES P, HARMAND J-M \&VAAST P. 2010. Effects of Inga densiflora on the microclimate of coffee (Coffea arabica L.) and overall biomass under optimal growing conditions in Costa Rica. Agrofor Syst 78: 269-286.

TAMANG B, ANDREU MG \& ROCKWOOD DL. 2010. Microclimate patterns on the leeside of single-row tree windbreaks during different weather conditions in Florida farms: implications for improved crop production. Agrofor Syst 79: 111-122.

\section{How to cite}

BOSI C, PEZZOPANE JRM \& SENTELHAS PC. 2020. Silvopastoral system with Eucalyptus as a strategy for mitigating the effects of climate change on Brazilian pasturelands. An Acad Bras Cienc 92: e20180425. DOI 10.1590/0001-3765202020180425.

Manuscript received on March 30, 2018; accepted for publication on December 4, 2018

\section{CRISTIAM BOSI ${ }^{1}$}

https://orcid.org/0000-0001-8318-6477

\section{JOSÉ RICARDO M. PEZZOPANE ${ }^{2}$}

https://orcid.org/0000-0001-5462-6090

\section{PAULO CESAR SENTELHAS ${ }^{1}$}

https://orcid.org/0000-0002-9277-6871

${ }^{1}$ Universidade de São Paulo/ESALQ, Av. Pádua

Dias, 11, 13418-900 Piracicaba, SP, Brazil

${ }^{2}$ Embrapa Pecuária Sudeste, Rodovia Washington Luiz, Km

234, Caixa Postal 339, 13563-776 São Carlos, SP, Brazil

Correspondence to: Cristiam Bosi

E-mail:cristiambosi@yahoo.com.br

\section{Author contributions}

Cristiam Bosi performed the literature review, data collection, data analysis and wrote the paper. José Ricardo Macedo Pezzopane helped in the design of methodology, data collection, data analysis and article writing. Paulo Cesar Sentelhas helped in the design of methodology, data analysis and article writing.

\section{(cc) BY}

